\title{
Relationship Between Leadership, Resilience, and Competence Amongst Police Officers in Klang Valley, Malaysia
}

\author{
Fazura Razali ${ }^{1}$, Ahmad Aizuddin Md Rami ${ }^{1}$, Nur Shuhamin Nazuri ${ }^{2}$, Siti Shazwani Ahmad Suhaimi ${ }^{2}$ \\ ${ }^{1}$ Faculty of Educational Studies, Universiti Putra Malaysia, Serdang, Selangor, Malaysia \\ ${ }^{2}$ Faculty of Human Ecology, Universiti Putra Malaysia, Serdang, Selangor, Malaysia \\ Correspondence: Ahmad Aizuddin Md Rami, Faculty of Educational Studies, Universiti Putra Malaysia, 43400 \\ UPM Serdang, Selangor, Malaysia. Tel: 603-9769-7922. E-mail: ahmadaizuddin@upm.edu.my
}

Received: September 3, $2021 \quad$ Accepted: September 28, $2021 \quad$ Online Published: October 14, 2021

doi:10.5539/ass.v17n11p39 URL: https://doi.org/10.5539/ass.v17n11p39

\begin{abstract}
Excellent human resource development prioritizes organizational performance development elements. Organizational performance in Malaysia's public sector is a concept that still needs to be explored. To date, improvements to leadership quality in order to enhance employee competence is one of the areas of study that has become the focus of researchers in the field of human resource development. In fact, leadership quality is also influenced by a person's self-resilience to changes - one such example is police officers' competence in order to perform their duties well. This study aims to assess the relationship between self-resilience and the leadership qualities of police officers. The study involved the Royal Malaysia Police of the state of Selangor. The study which used a simple randomized quantitative method involved 105 respondents comprised of police officers and other members of the force. Findings of the study indicate highest positive relationships between leadership and competency, resilience and competency, and resilience and leadership, with $r$ values between 0.791 to 0.864 . However, the relationship between leadership quality based on education level and length of service (work experience) was not significant. This study shows that there are several elements in human resource development and performance management that can be improved by emphasizing on the leadership aspect in order to improve the competencies of police officers in Malaysia.
\end{abstract}

Keywords: competency, leadership, police officer, resilience

\section{Introduction}

The ever-changing and increasingly complex structure of organizations has challenged all companies to develop their respective human resource potential. Human resource development has become an important element in excellent organizations in line with the current world's challenges (Rami et al., 2021) as well as the 12th Malaysia Plan which one of its aims is to enhance human resource research and development (RMK-12, 2020). Even in the 11th Malaysia Plan (RMK-11), human resource development is seen as a critical factor in generating and sustaining Malaysia's economic growth (11th Malaysia Plan, 2015; 12th Malaysia Plan, 2020). The Human Development Report (2019) also explained that the development of human resources is an important element that needs to be given more serious attention through programs and action plans formed holistically and comprehensively to ensure the best quality of human resources (The United Nations Development Program, 2019). Up until the third quarter of 2019, civil service posts have shown an increase of 0.1 million from the 1.6 million in 2018, and this covers the federal civil service, federal statutory bodies, state civil service, state statutory bodies, and local authorities (Statistics Malaysia, 2020). As much as 62\% of the total size of civil service posts are in health, education, as well as the security forces sectors (Maidin. 2019). As of $31^{\text {st }}$ November 2019, the Royal Malaysian Police (PDRM) recorded 114,688 posts which is $7.64 \%$ of the $62 \%$ of the total civil service posts aforementioned, and this percentage includes all departments, contingents, formations, brigades, and districts (PDRM, 2019). However, the most worrying issue is when a total of 51,668 police officers had stated that misconduct still exists in PDRM - this fact has affected PDRM's services and forced the organization to become an agency focused instead on addressing the issue of misconduct through the establishment of the 2020 Independent Police Conduct Commission (IPCC), according to the outcome of a questionnaire analysis. The 2020-2024 Pelan Antirasuah Polis Diraja Malaysia (PAPDRM) listed that the risk of corruption is at 11.48, followed by the risk of integrity at 4.36 (PDRM, 2020). 


\subsection{Police Officers' Competency}

Competencies in the context of PDRM focus on the chronology of promotion which is earned based on 22 sub-criteria contained in 5 main competency criteria. Other human resource management functions, on the other hand, are implemented selectively in bits and pieces (PDRM, 2015). However, an analysis of the PAPDRM questionnaire data showed that although various approaches have been implemented by PDRM, misconduct still exists within police personnel, a fact that has affected the organization's quality of service (PDRM, 2020). This is because the element of competency in the career development of a police officer is highly dependent on the factor of reputation or good relationship with superior officers (Haase, 2007; Hogget, 2018). This statement is supported by Tasriff et al. (2016) and Ahamada et al. (2018), who stated that employee competency profiles are usually based on individual strategies as opposed to strategies undertaken by organizations. This indicates that organizational strategies need to be strengthened in order to ensure that employee competencies are at the best level (Tasriff et al., 2016; Ahamada et al., 2018; Lin \& Kim, 2019).

\subsection{Leadership Quality}

Leadership quality has been seen to have huge implications on career development, especially in terms of employee competencies. It has a significant relationship with flexible leadership quality and aligns with the achievements targeted by organizations in various sectors (Aziz et al., 2020). Flexibility is defined as being parallel with internal trends intended to make the right changes in order to develop the competencies needed by an organization (Charles, 2013). On the other hand, a flexible leadership style refers to the way leaders interpret situational clues and adjust their decisions, behaviors, and actions to achieve desired goals (Good \& Sharma, 2010; Baron et al., 2018; Yukl \& Mahsud, 2010; Yukl, 2012). In fact, career development has a significant relationship with competencies in job performance (Arifin et al., 2020) and leadership roles and qualities (Bakri et al., 2009). Quality leaders must have complete information in order to make decisions and ensure that the decisions made are fair and able to provide satisfaction to employees involved without being influenced by other sources (Mansor \& Hamzah, 2015).

\subsection{Resilience}

The level of resilience in a leader is a key factor in ensuring that leadership qualities can be practiced effectively (Becker, 2002). It is also highly important in organizations that are always in unforeseen situations and need to make urgent decisions in accordance with the passage of time (Dirani et al., 2020). According to Southwick et al. (2017), a leader's self-resilience is seen through the way he adapts when dealing with issues and problems that arise. Various factors can influence a leader's self-resilience - it starts from the leader's own self and is based on the experience and environment of the individual as well as how these elements are developed and implemented in organizational leadership.

To ensure that employees have the quality and competence that organizations need, there should be processes to help employees remain competitive in a healthy way (Rusilowati \& Maulida, 2020). Organizations should focus on healthy competition amongst employees which can be created through competency determination and positive career development as both do enhance organizational productivity (Hasan et al., 2020). Competency planning and assessment allows employees to know their own qualifications in order to pursue the next steps in their careers (Salleh et al., 2007). However, there are still various issues involving police officers' competency, more so in delivering services and performing assigned tasks. According to Filstad and Karp (2020), this is because currently, it is standard practice for the police to 'take care of each other', therefore explaining why promotion or competency is based on reputation factors or good relationships with superior officers rather than job performance (Haase, 2007; Hoggett, 2018).

Filstad and Karp (2020) stressed that in security forces, leaders should always be prepared and professional in ensuring their subordinates' competency in order to maintain the continuity of difficult and challenging tasks as a team. Police officers should always be given the space and opportunity in career development with the aim of enhancing their competencies. Therefore, research into police leadership quality requires more attention that is based on the understanding of the development of police officer competencies through leadership. Dirani et al. (2020) stated that the quality of leadership is portrayed as being able to respond to unforeseen changes in new or challenging situations, and this factor highly affects employee competencies. Thus, leaders should be able to adjust their own competencies in order to respond professionally in reference to other elements under human resource development in order to pursue the best competencies and remain competitive.

As mentioned earlier, a leader's self-resilience is seen through the way they adapt in dealing with issues and problems that arise in an organization. Various factors can influence a leader's self-resilience; nonetheless, it starts from one's own self and is based on the individual's experience and environment as well as how these 
elements are developed, implemented and translated into leadership qualities needed by an organization (Southwick et al., 2017; Becker, 2002). Self-resilience's influence on leadership quality can also help improve employee competence, therefore enabling employees to perform quality work which in itself is a form of direct support to the organization in order to grow sustainably (Helmi et al., 2020). A study on the effect of leader personality on self-resilience found that employees evaluate the emotions of relationships with leaders who share the same leadership values (Campbell \& Kodz, 2011).

This study combined two theories, namely the Competency Motivation Theory (Hartes, 1981) and the Resilience Theory (Kaplan et al., 1996) with a model, namely the Transformational Leadership Model (Ha-Vikström, T., \& Takala, 2016) to structure the research framework. The Competency Motivation Theory emphasizes on the element of competence in police officers. This element requires the direct involvement and support of department heads and supervisors. This theory sees organizational support as an essential element in determining employee competencies, not just employee strategies in ensuring career development.

The primary purpose of this study is to look at the relationship between self-resilience in leadership and the quality of competence possessed by police officers in the Selangor contingent. Past studies on security forces have shown that the competency assessment elements for the career development of police officers are highly dependent on reputational factors or good relationships with superior officers (Haase, 2007). This statement is supported by Tasriff et al. (2016), and Mahmood et al. (2018) who mentioned that employee competency profiles are based on individual strategies instead of strategies undertaken by organizations. Organizations therefore need to implement additional strengthening on their organizational strategy in order to ensure that their employees' competencies are at the best level (Tasriff et al., 2016; Mahmood et al., 2018). Although this study is not the first conducted on the police profession, it still has its attraction as it involves the competency levels of PDRM police officers, the principal enforcement agency in Malaysia that is constantly faced with various pressures and unforeseen situations. Based on the existing gaps identified above, the authors propose the following competing hypotheses:

$\mathrm{H} 1=$ There are significant differences in the impacts of leadership quality, competency, and self-resilience on the level of education

$\mathrm{H} 2=$ There are significant differences in the impacts of leadership quality, competency, and self-resilience on the year of service

H3= There are significant relationships between leadership quality, competency, and self-resilience

\section{Methods}

The study was conducted at the Serdang District Police Headquarters, Selangor since the number of public officers in the Serdang District Police Headquarters are greater compared to other districts in the State of Selangor. The total population of police officers in Serdang Districts are 1100. This study used the quantitative research approach and stratified random sampling method to ensure that the selected sample reflects the characteristics of the population studied. Sample selection was conducted on police officers with the ranks of $\mathrm{ACP}$ up to Konst/S. The sampling was randomly carried out using a simple computerized random number. Data were collected using a questionnaire distributed via Google Form. The researcher managed to collect data around 105 respondents. The dependent variable in this study is competency, while the independent variables are leadership quality and self-resilience. There were three sets of instruments used to measure every variable; the first is the Career Competencies Indicator (CCI) instrument which involves measuring the competencies of police officers, while the second is the Multiple Leadership Questionnaire (MLQ) which measures leadership quality. Additionally, self-resilience was measured using The Connor-Davidson Resilience Scale (CRQ) from the perspective of department heads and supervisors. A five-point Likert scale was used as the answer scale for all instruments. The questionnaire contains 66 items and is divided into 4 sections namely Section A (Demographics), Section B (21 items from the CCI), Section C (20 items from the MLQ), and Section D (25 items from the CD-RISC). After the data collection process, the findings of this study were then analyzed using SPSS version 26.0. Descriptive statistics such as frequency, percentage, mean, and standard deviation were used to fulfil the determined objective. Inferential analyses such as the independent t-test and ANOVA were used to determine any differences between the sociodemographic variables. Pearson correlation was used to determine whether there are relationships between variables. Table 1 shows the results which prove the high reliability of instruments measuring the variables. Competency, leadership quality and self-resilience demonstrated high values of Cronbach alpha ranging from 0.987 to 0.989 . These numbers reveal that items employed in this study possess high internal consistency as each set of items are closely related to each other as a group. 
Table 1. Reliability test

\begin{tabular}{cc}
\hline Variable & Cronbach Alpha, $\alpha$ \\
\hline Competency & .987 \\
Leadership Quality & .989 \\
Self-Resilience & .987 \\
\hline
\end{tabular}

\section{Results}

\subsection{Respondents' Demographics}

The demographic profile of the selected sample population included age, rank, level of education, and years of service. The sample was spread out among all age groups: ages 21-30 had 26 respondents (24.8\%), ages 22-24 years had 45 respondents (42.9\%), 25 respondents (23.8\%) were between 25-29 years old, and 9 respondents are aged 51-60 (8.6\%). Among these respondents, $47(44.8 \%)$ are INSP/P - ASP, 36 (34.3\%) are Konts/S - KPL, 16 (15.2\%) are Sarjan, 5(4.8\%) are DSP-SUPT, and 1(1\%) is ACP and above. Regarding the respondents' level of education, an almost equivalent number represented all categories - $56(53.3 \%)$ possess tertiary education certification, while $80(46.7 \%)$ finished their secondary education. In terms of years of service, $42.9 \%$ (45) have less than 10 years of service, 30 (28.6\%) have between 11-20 years of service, and $26(24.8 \%)$ have 21 years and above.

Table 2. Demographic Respondents

\begin{tabular}{|c|c|c|}
\hline Variable & Frequency (n) & Percentage $(\%)$ \\
\hline \multicolumn{3}{|l|}{ Age } \\
\hline 21-30 years old & 26 & 24.8 \\
\hline 22-24 years old & 45 & 42.9 \\
\hline 25-29 years old & 25 & 23.8 \\
\hline 51-60 years old & 9 & 8.6 \\
\hline \multicolumn{3}{|l|}{ Rank } \\
\hline Konts/S - KPL & 36 & 34.3 \\
\hline Sarjan - SI & 16 & 15.2 \\
\hline INSP/P - ASP & 47 & 44.8 \\
\hline DSP - SUPT & 5 & 4.8 \\
\hline $\mathrm{ACP}$ and above & 1 & 1 \\
\hline \multicolumn{3}{|l|}{ Level of Education } \\
\hline Secondary & 49 & 46.7 \\
\hline Tertiary & 56 & 53.3 \\
\hline \multicolumn{3}{|l|}{ Years of Service } \\
\hline 10 years and below & 45 & 42.9 \\
\hline 11-20 years & 30 & 28.6 \\
\hline 21 years and above & 30 & 28.6 \\
\hline
\end{tabular}

\subsection{Respondents'Levels of Leadership Quality, Competency, and Self-Resilience}

The results shown in Table 3 prove that most respondents have high levels of competency, leadership and resilience as these elements accounted for $85.7 \%, 76.2 \%$ and $89.5 \%$ of the respondents, respectively. These results indicate that there exists high levels of competency, leadership and resilience amongst the police officers of the Klang Valley area.

Table 3. Summary of Descriptive Analysis

\begin{tabular}{ccccc}
\hline Variable & Frequency $(\mathrm{n})$ & Percentage $(\%)$ & Mean & SD \\
\hline Competency & 7 & & & \\
Low & 8 & 6.7 & 4.061 & 0.885 \\
Moderate & 90 & 7.6 & & \\
High & 90.7 & & \\
\hline
\end{tabular}




\begin{tabular}{|c|c|c|c|c|}
\hline Leadership & & & \multirow{4}{*}{3.961} & \multirow{4}{*}{0.924} \\
\hline Low & 7 & 6.7 & & \\
\hline Moderate & 18 & 17.1 & & \\
\hline High & 80 & 76.2 & & \\
\hline \multicolumn{5}{|l|}{ Resilience } \\
\hline Low & 6 & 5.7 & \multirow{3}{*}{4.119} & \multirow{3}{*}{0.851} \\
\hline Moderate & 5 & 4.8 & & \\
\hline High & 94 & 89.5 & & \\
\hline
\end{tabular}

3.3 Comparison of Competency, Leadership and Resilience for the Different Levels of Education Groups Using the Independent Sample T-test

One of the focal points of this study is to inspect if there is any relationship between the respondents' level of education with competency, leadership and resilience. Based on the independent sample t-test performed in Table 4 , the results conclude that there is no significant difference found between competency, leadership and resilience and the respondents' level of education. The results of the findings contradict the findings of previous studies done by Freifeld (2013), Mansor et al. (2015), and Dimopoulos (2020), who asserted that the quality of a leader is seen in career experience as it is able to contribute to producing the best performance and achievement in an organization.

Table 4. Comparison of competency, leadership and resilience for the different levels of education groups using the independent sample t-test

\begin{tabular}{cccccc}
\hline Variables & Level of education & $\mathrm{n}$ & Mean & $\mathrm{t}$ value & $\mathrm{p}$ \\
\hline Competency & Secondary Education & 49 & 3.909 & -1.667 & 0.099 \\
& Tertiary Education & 56 & 4.195 & & 0.276 \\
Leadership & Secondary Education & 49 & 3.855 & -1.095 & \\
& Tertiary Education & 56 & 4.053 & & 0.062 \\
& Secondary Education & 49 & 3.953 & -1.890 & \\
& Tertiary Education & 56 & 4.264 & & \\
& Resilience & & &
\end{tabular}

Mean scores are based on a Likert scale of $1-5$, where 5 is the highest.

Significance at the 0.05 level (2-tailed).

3.4 Comparison of Competency, Leadership and Resilience for Differences in Length of Service (Years) Using the ANOVA Analysis

The length of one's service has become a major thing in almost every issue, including competency, leadership and resilience. This study noticed that the respondents' length of service does not have any significant difference on their competency, leadership and resilience. The result is inconsistent with findings by Freifeld (2013), Mansor et al. (2015), and Dimopoulos (2020) who asserted that a leader's quality is seen by having the knowledge needed to be able to contribute in terms of giving the best performance and achievement to an organization.

Table 5. Comparison of competency, leadership and resilience foe differences in length of service (years) using the ANOVA analysis

\begin{tabular}{|c|c|c|c|c|c|}
\hline Variable & Year & $\mathrm{N}$ & Mean & $\mathrm{F}$ & $\mathrm{p}$ \\
\hline \multirow{4}{*}{ Competency } & 10 years and below & 45 & 4.032 & \multirow{4}{*}{0.348} & \multirow{4}{*}{0.707} \\
\hline & $11-20$ years & 30 & 3.994 & & \\
\hline & 21 years and above & 30 & 4.173 & & \\
\hline & 10 years and below & 45 & 3.794 & & \\
\hline \multirow[t]{2}{*}{ Leadership } & $11-20$ years & 30 & 3.928 & \multirow[t]{3}{*}{2.184} & \multirow[t]{2}{*}{0.118} \\
\hline & 21 years and above & 30 & 4.242 & & \\
\hline \multirow{3}{*}{ Resilience } & 10 years and below & 45 & 4.039 & & \multirow{3}{*}{0.497} \\
\hline & $11-20$ years & 30 & 4.084 & \multirow[t]{2}{*}{0.704} & \\
\hline & 21 years and above & 30 & 4.272 & & \\
\hline
\end{tabular}

Mean scores are based on the Likert scale $1-5$, where 5 is the highest.

Significant at the 0.05 level (2-tailed). 


\subsection{Relationships Between Competency, Leadership and Resilience}

Finally, Table 6 presents the Pearson correlations on the elements of competency, leadership and resilience. Notably, the highest positive relationships are observed between leadership and competency, resilience and competency, and resilience and leadership, with $\mathrm{r}$ values between $0.791-0.864$. These findings coincide with the findings of Ibrahim (2017) who stated that career development strategies are able to determine the culture of organizational development in creating and improving competencies amongst employees to be in line with organizational aspirations. This is to ensure that there are no inconsistencies in work procedures set by the organization, and also to ensure that all employees comply with work procedures that have been set so as to guarantee the best quality of service is given to an organization (Southwick et al., 2017; Dirani et al., 2020).

Table 6. Correlation analysis

\begin{tabular}{cccc}
\hline & 1 & 2 & 3 \\
\hline Competency & 1.000 & & \\
Leadership & $0.791^{* *}$ & 1.000 & \\
Resilience & $0.864^{* *}$ & $0.808^{* *}$ & 1.000 \\
\hline
\end{tabular}

**Significance at the 0.01 level (2-tailed).

\section{Discussion and Conclusion}

After presenting the results, you are in a position to evaluate and interpret their implications, especially with Generally, based on this study's analysis, a majority of the respondents are 22-24 years old, hold the rank of INSP/P, have completed the tertiary level of education, and have 10 years of service. For the correlation analysis, the findings indicate that the relationships between leadership quality, competency and self-resilience are positively significant. The results of this study can be used to further develop ideas related to leadership as presented by Dirani et al. (2020) who highlighted ideas related to the behaviors of organizational leaders and its influence on followers. Ethical leadership indeed plays an important role in influencing the behaviors of police officers to support organizational commitment. Leaders should always provide the space and opportunity in career development in order to enhance the competencies of police officers and allow them to remain relevant (Filstad \& Karp, 2020). Dirani et al. (2020) also stated that a characteristic of a quality leader is to have self-resilience which is defined as having a way of thinking that is easily adaptable when in unforeseen situations and is able to make urgent decisions. These important qualities indicate that this element is necessary in addressing the current challenges faced by organizations in crisis situations as these environments are highly unpredictable, even over time. The transformational leadership theory suggests that leaders who exhibit human-oriented behaviors, justice, power-sharing, concern for sustainability, ethical guidance, role clarification, and integrity will be more successful in influencing police officer competence (Filstad, 2020). This study also contributes to knowledge on the theories used, namely the leadership theory and competency theory, which forms the main framework of this study. The findings of this study can also help the PDRM in selecting qualified police officers whose promotions are not only based on seniority but also according to their level of competence. In other words, police officers must be appointed to higher ranks or placements on the basis of their competencies as shown in the findings of Haase (2007), Hoggett et al. (2019), and Filstad and Karp (2020) rather than by using current police practices such as 'taking care of each other' or reputational factors such as maintaining good relationships with superior officers. Specifically, PDRM can use the findings of this study to plan, build, and improve their career development programs to further enhance the competencies of its police officers. The results can also be used as a guide to improve the quality of service and work among PDRM police officers. It is important to ensure that the services provided by PDRM can be one that brings pride to the country based on an excellent organizational culture that helps form a team that not only prioritizes its customers, but also the performance of the services provided. The study findings also add to the body of knowledge, especially in the fields used by PDRM leadership practitioners and policymakers of the Security and Public Order in Malaysia. Overall, the human-oriented dimension and ethical guidance should be taken as important elements in planning PDRM's competency management. Although this study is not the first to be conducted in the police profession, it still has its own attraction for the relevant parties to study the issue in more detail as PDRM police officers make up the main enforcement agency in Malaysia which always faces various pressures and unforeseen situations

\section{Acknowledgments}

This research was done in collaboration with the Director of Standards Compliance and Integrity Department, 
Royal Malaysian Police (PDRM), the Deputy Director of Management (Training) Royal Malaysian Police (PDRM), Senior and Junior Police Officers of the Royal Malaysian Police (PDRM) in Klang Valley, and funding from Faculty of educational Studies, Universiti Putra Malaysia.

\section{References}

Ahamada, M., Norb, M. M., \& Alic, N. R. M. (2018). Persepsi pekerja terhadap strategi pembangunan kerjaya individu dan organisasi di Edaran Otomobil Nasional Berhad (EON Berhad). Management Research Journal, 8(1), 157-174.

Arifin, A. H., Raza, H., Saputra, J., \& Puteh, A. (2020). The Influence of Recruitment and Career Development towards Employee Performance: A Mediating Role of Competence. Journal of Talent Development and Excellence, 12(1), 1040-1055.

Arifin, A. H., Raza, H., Saputra, J., \& Puteh, A. (2020). The Influence of recruitment and career development toward employee performance: A mediating role of competence, talent development \& excellence, 12(1), 1040-1055.

Aziz, F., Md Rami, A., Razali, F., \& Mahadi, N. (2020). The influence of leadership style toward technology acceptance in organization. International Journal of Advanced Science and Technology, 29(7), 218-225.

Bakri, N., Kiong, Y. S., \& Hussin, H. (2009). Hubungan antara peranan individu dan organisasi dengan amalan pembangunan kerjaya, 2(1).

Becker, D. (2002). Magazine of Business Harvard Review. May 2002 Edition. Retrieved from https://hbr.org/2002/05/how-resilience-works

Campbell, I., \& Kodz, J. (2011). What makes great police leadership? What research can tell us about the effectiveness of different leadership styles, competencies and behaviours. A Rapid Evidence Review Research, Analysis \& Information (RAI).

Darvish, H., Moogali, A., \& Moosavi, M. (2012). An empirical study on human resource competencies and its relationship with productivity. Management Science Letters, 2(7), 2615-2624. https://doi.org/10.5267/j.msl.2012.07.001

De Castro, C. A. (2013). Contextual influences on Human Resources Development: Considerations and evaluations on the various external and internal factors that shape and influence HRD in organisations. Internacionalização - Edição Especial..

Dimopoulos, D. (2020). Educational leadership effectiveness. Is it a matter of a leader's characteristics, behaviors, or leadership style? Journal of Economics and Management Sciences, 3(1), 13. https://doi.org/10.30560/jems.v3n1p13

Dirani, K. M., Abadi, M., Alizadeh, A., Barhate, B., Garza, R. C., Gunasekara, N., ... Majzun, Z. (2020). Leadership competencies and the essential role of Human Resource Development in times of crisis: A response to COVID-19 pandemic. Human Resource Development International. https://doi.org.10.1080/13678868.2020.1780078

Filstad, C., \& Karp, T. (2020). Police leadership as a professional practice. Policing and society: An International Journal of Research and Policy. https://doi.org/10.1080/10439463.2020.1777996

Freifeld, L. (2013). Emerging Traininsg Leaders. Training, 50(3), 20-31.

Garavan, T., Shanahan, V., Carbery, R., \& Watson, S. (2016). Strategic human resource development: Toward a conceptual framework to understand its contribution to dynamic capabilities. Human Resource Development International. https://doi.org/10.1080/13678868.2016.1169765

George, D., \& Mallery, M. (2003). Using SPSS For Windows step by step: A simple guide and reference. Boston, MA: Allyn y Bacon.

Good, D. J., \& Sharma, G. (2010). A little more rigidity: Firming the construct of leader flexibility. Journal of Change Management, 10(2), 155-174. https://doi.org/10.1080/14697011003795636

Haakea, U., Rantatalob, O., \& Ola Lindberga, O. (2015). Police leaders make poor change agents: Leadership practice in the face of major organisational reform. Policing and Society. https://doi.org/10.1080/10439463.2015.1099653

Haase, S. (2007). Applying Career Competencies in Career Management (Doctoral dissertation, Coventry University in collaboration with the University of Worcester). 
Hamad, F., \& Mahidy, A. (2018). Term Human Resource Development is combining to some HRM concept of Human Recourse Development. https://doi.org.10.13140/RG.2.2.34328.65285

Halim, F., \& Ahmad. Z. H. (2013). Pengaruh Ketidakakuran Sivil Terhadap Profesionalisme Anggota PDRM. Jurnal Psikologi Malaysia, 27, 119-134.

Hanafiah, M. H., Ismail, H., \& Tasirin, J. A. (2002). Siri Pengurusan Sumber Manusia mencari dan mengekalkan pekerja terbaik (pp. 221-257). Edisi Pertama. Petaling Jaya: Prentice Hall Pearson Malaysia.

Ha-Vikström, T., \& Takala, J. (2016). Knowledge management and analytical modeling for transformational leadership profiles in a multinational company. In Successes and failures of knowledge management (pp. 151-173). Morgan Kaufmann. https://doi.org/10.1016/B978-0-12-805187-0.00011-5

Herd, A., \& Alagaraja, M. (2016). Strategic Human Resource Development Alignment: Conceptualization from the Employee's Perspective. In Project Management: Concepts, Methodologies, Tools, and Applications, Chapter 73. https://doi.org/10.4018/978-1-5225-0196-1.ch073

Helmi, R. L. (2020). Knowledge Management Enabler (KME) to Promote Innovation Capabilities in Public $\mathrm{R} \& \mathrm{D}$ Centers in Indonesia. The Asian Journal of Technology Management, 13(2), 98-112. https://doi.org/10.12695/ajtm.2020.13.2.1

Hoggett, J., Redford, P., Toher, D., \& White, P. (2019). Challenges for police leadership: Identity, experience, legitimacy and direct entry. Journal of Police and Criminal Psychology, 34(2), 145-155. https://doi.org/10.1007/s11896-018-9264-2

Ibrahim, M. A., Sulaiman, W. S. W., Aziz, S. F. A., \& Hafidz, S. W. M. (2017). Peranan Kepuasan Kerja Sebagai Mediator Dalam Hubungan Antara Budaya Organisasi Dan Tingkah Laku Kewargaan Organisasi Dalam Kalangan Anggota Polis. Tema: Isu-Isu Kesejahteraan Masyarakat Malaysia. Journal of Social Sciences and Humanities, eBangi - Special Issue 3.

Kaplan, C. P., Turner, S., Norman, E., \& Stillson, K. (1996). Promoting resilience strategies: A modified consultation model. Children \& Schools, 18(3), 158-168. https://doi.org/10.1093/cs/18.3.158

Kurniawan, E., Bandono, A., Krembangan, \& Bumimoro-moro. (2012). The Influence of Competency Factors, Career Development.

Lin, D., \& Kim, S. (2020). To improve employee career success through organizational development intervention: An action research of AIA Co., Ltd. Changzhou Branch. ABAC ODI Journal Vision. Action. Outcome 7(1).

Maidin, M. H. (2019). Malaysia Kini. Retrieved from https://www.malaysiakini.com/news/503576

Mansor, R., \& Hamzah, M. I. M. (2015). Kepimpinan berkualiti: Perspektif mengenai kompetensi yang diperlukan untuk memimpin dengan berkesan. Jurnal Pengurusan (UKM Journal of Management), 45,143-154. https://doi.org/10.17576/pengurusan-2015-45-13

Mahmood, R., Hee, O. C., Yin, O. S., \& Hamli, M. S. H. (2018). The mediating effects of employee competency on the relationship between training functions and employee performance. International Journal of Academic Research in Business and Social Sciences, 8(7), 664-676. https://doi.org/10.6007/IJARBSS/v8-i7/4410

Polis Diraja Malaysia. (2015). Literasi Kompetensi Unit Dasar Sumber Manusia. Jabatan Pengurusan. Polis Diraja Malaysia (2015-2020).

Polis Diraja Malaysia. (2019). Laporan Audit Perjawatan. Unit Audit Perjawatan. Jabatan Pengurusan.

Polis Diraja Malaysia. (2020). Pelan Antirasuah Polis Diraja Malaysia (2020-2024).

Rami, A. M., Aziz, F., Razali, F., \& Ibrahim, A. (2020). Effective local leadership to a successful council in the state of Terengganu, Malaysia. International Journal of Advanced Science and Technology, 29(7), 205-210.

Rami, A. M., Aziz, F., Zaremohzzabieh, Z., \& Ibrahim, A. (2021). Assessing the Challenges of Local Leaders in Rural Community Development: A Qualitative Study in Malaysia. Pertanika Journal of Social Sciences \& Humanities, 29, 1-18. https://doi.org/10.47836/pjssh.29.S1.01

Rancangan Malaysia Ke-11 \& Dasar Sumber Manusia Negara (Pelan Strategik Kementerian Sumber Manusia 2016 - 2020) Bil. DSMN RMK11 Maklum Balas Teras Strategi Pelan Tindakan. Retrieved from https//:www.mohr.gov.my

Rancangan Malaysia Ke-12 \& Dasar Sumber Manusia Negara (Pelan Strategik Kementerian Sumber Manusia 
2020 - 2025) Bil. DSMN RMK12 Maklum Balas Teras Strategi Pelan Tindakan. Retrieved from https//:www.mohr.gov.my

Rusilowati, U., \& Maulida, H. (2020). Effect of Competence and Career Development on Turnover and Its Impact on Productivity. Jurnal Manajemen, 24(1), 59-73. https://doi.org/10.24912/jm.v24i1.618

Salleh, M. M. (2007). Kepimpinan dan pengurusan strategik di institusi pendidikan MARA. Tesis PhD tidak terbit. Universiti Kebangsaan Malaysia.

Southwick, F. S., Martini, B. L., Charney, D. S., \& Southwick, S. M. (2017). Leadership and resilience. August Issue, 315-333. https://doi.org/10.1007/978-3-319-31036-7_18

Tasriff, S. R. F., Rahman, R. A., Rahmanb, A. A., \& Patahc, S. A. (2016). Efikasi kendiri dan strategi pembangunan kerjaya kakitangan sokongan. Journal of Advanced Research in Social and Behavioural Sciences, 4(2), 125-135.

Yukl, G., \& Mahsud, R. (2010). Why flexible and adaptive leadership is essential. Consulting Psychology Journal: Practice and Research, 62(2), 81-93. https://doi.org/10.1037/a0019835

Yukl, G. (2012). Effective leadership behavior: What we know and what questions need more attention. Academy of Management perspectives, 26(4), 66-85. https://doi.org/10.5465/amp.2012.0088

\section{Copyrights}

Copyright for this article is retained by the author(s), with first publication rights granted to the journal.

This is an open-access article distributed under the terms and conditions of the Creative Commons Attribution license (http://creativecommons.org/licenses/by/4.0/). 